\title{
Literature Courses in EFL Curriculum: Pre-Service Language Teachers' Perceptions
}

\author{
Mustafa Zeki ÇIRAKLI $\&$ Ferit KILIÇKAYA**
}

\begin{abstract}
This study is designed to explore how literature lessons are perceived by pre-service English language teaching (ELT) students and discusses the findings in terms of student perceptions and educational objectives. The participants were 30 Turkish EFL senior students. Both quantitative and qualitative measures were used to collect data in order to validate the findings. The results showed that pre-service teachers highly valued the literature courses. The participants, however, recommended that the literature courses should not be restricted to the canonic texts and aim to develop linguistic abilities through critical literary readings and cultural interpretative efforts.
\end{abstract}

Keywords: English literature, pre-service language teachers, Turkey, ELT

\footnotetext{
${ }^{*}$ Yrd. Doç. Dr., Karadeniz Teknik Üniversitesi, İngiliz Edebiyatı

** Araş. Gör., Orta Doğu Teknik Üniversitesi, Yabancı Diller Eğitimi Bölümü
} 


\section{Introduction}

Reading for pleasure or out of curiosity and private study traces back to ancient times and is expected to "...go on long after literature has been disestablished from the educational curriculum or changed out of all recognition" (Hall, 2005, p. 42). Although partly excluded from English language teaching (ELT) programs, literature is a crucial subject of curriculum developed by ELT and LanguageLiterature departments in Turkey and appears to be an important issue in the timetable. A quick look at the present practice in Turkey shows that literature classes are mostly concerned with appropriate anthologies and syllabuses of 'canonic' authors and texts. In recent years, many educators in both fields have again acknowledged the academic, intellectual, cultural, and linguistic benefits of the study of literature and educational departments reviewed and revised their attitude towards literature classes. However, as far as what practical benefits we expect from literature education in ELT classes are concerned, in Turkey, integrating literature to already established ELT curriculum presents some complications. This article considers how literature lessons are perceived by the prospective English teachers and discusses the findings in terms of their perceptions and educational objectives.

\section{Literature review}

This paper launches from the premise that literature can make positive contributions to EFL classes and attempts to answer what is claimed to be learned from reading, studying, discussing and writing about literature in educational contexts. Literary texts can be motivating and thought-provoking and provide the facilitators and the learners with meaningful (and memorable) contexts adopting new concepts/vocabulary and structures/paradigms. According to McRae (1991), literary texts may function as both referential language and representational language. While the former prioritizes communication mostly practiced through social situations, the latter requires decoding and engages imagination ((McRae, $\mathrm{p}$. 3). Thus, it can be stated that while referential language "informs", representational language "involves." McRae stresses the role of the representational language offered by literary texts in the development of language learning abilities and enable the student to develop different ways of seeing the world. Considering the above classification and the significance of literature in EFL classes, Ferradas (2009) argues that literature may help to thrive linguistic and cultural awareness and serve to perceive/receive socio-cultural issues from different perspectives since it stimulates imagination in addition to recreate social and individual contexts. Thus, the aim should not be restricted to mere literary analysis of certain texts and literature should be considered in "educating the whole person". Hall poses the question "what is the place of literature in education?" and explores how literature and language relate to culture. He stresses creative strategies and cultural awareness and argues that efficient literature classes can provide this. This also helps to develop linguistic abilities through critical literary readings and cultural interpretative efforts. $\mathrm{He}$ also underlines the significance of developing a view of cultural plurality and a sense of individual ethics and emphasizes the making of "worthier - or perhaps more critical citizens" (p. 39). He concludes "literature for many broadens our notions of what it means to be human, and how we could live better as human beings" (p. 39). For this aim, he proposes that "literariness" (representational texts where linguistic elements are underplayed) and "communicativeness" (referential language where linguistic issues are focused) should be better balanced and better integrated (pp. 45-47). Similarly, Hussein (2007) lays emphasis on motivating power of literature and argues that literature "cultivates the critical abilities" (p. 115). She maintains that literary texts are better to deal with human conflicts than mechanical exercises and stresses the dialogic nature of literary texts, which foregrounds the student's creative faculty. Widdowson (1983) refers to the practical role taken over by the literary texts. He finds it inspirational but difficult. Widdowson seems to be concerned with the significance of representational aspect of the literary texts. He draws attention to "interpretation procedures" and in order to improve such procedural skills he gives a place for literature. Montgomery, Durant, Fabb, Furniss and Mills (2007) primarily consider the significance of comprehension techniques, which requires enhancing the ability of asking questions as a way into the texts, processing and using the information sources and analyzing the units of patterns and structures. By doing so, the student will recognize language variation that comprises the recognition of not only literary but also cultural elements such as context, gender, society and identity expressed through the representational language of literary texts. Montgomery et al. state, however, that debates have often been conducted in terms of theoretical analysis; but alongside such efforts there is an important need for materials (1). They lay "less emphasis on literature as such" (1) and stress the importance of exploration of "non-literary texts as well as literary texts" (1). In this sense Montgomery et al. argue that "focus on "rhetorical organization of texts", that is, "how they work to create meaning or how they produce recognizable effects," are of consideration.

As can be seen in the above effort to approach literary texts as a general instrument of all types of texts, Wright (2003) focuses on the significance of literature in EFL classroom since literature serves to humanize the learners as well as to expose second 
language medium. So, what Wright underlines is something beyond mere language teaching. She argues that literature [storytelling] is "an accepted and widely used approach in the teaching of English language classroom. It represents a holistic approach to language teaching and learning founded on the understanding that learners need to interact with rich, authentic examples of the foreign language" (Wright, 2003, p. 7). Furthermore, Garvie (1990) conceives literature as a vehicle for the cognitive and affective factors. Sivasubramaniam (2006) stresses emotional, imaginative and expressive use of language and refers to the two aspects of literature in EFL classrooms: language learning dimensions (language acquisition, cultural awareness, language awareness) and educational and social outcomes (educating human emotions, enhancing the imagination, improving individual and social sensitivity).

Considering the role of literature in EFL classrooms, it is observed that Information and Communication Technologies (ICTs) have been producing materials, who are involved in teaching language particularly through stories. It is also seen however that they are changing the nature of literary texts and generating new forms of literary narratives, including some video game narratives (Lunsworth, 2006). Premawardhena (2009) presents a Sri Lankan research, where renowned authors were integrated in the curriculum. The focus of the study was primarily on the surface level and vocabulary, and also on critical thinking, cultural awareness and aesthetic appreciation. The research shows that critical thinking, formulating and expressing independent opinions, interpretative skills and language competence can be improved by using literature. Moreover, Carter (2007) notes that literature has begun to assume a higher profile in contexts of second language education. Though more concerned with literature in adult EFL classrooms, Carter (p. 6) deals with the effects of the use of literature on "culture, language and personal growth". He deals with language as discourse and stresses the shift from "language" to "culture" through integrating literature (representational discourse) into the enterprise of language teaching, Tseng (2010) notes that students have more pleasure in reading contemporary literature rather than classic literature. Sivasubramaniam also draws attention to the problem of using canonical or non-canonical literary texts (259). Carter (2007) in his revisiting remarks made in Literature and language Teaching, conceives literary texts as a means of "contact with others' experience" (3) but focuses on the limits of Western canon and differentiates between texts by English Literature and texts by Literature in English (4).

Türker (1991), on the other hand, deals with the problems of EFL classrooms using literature in Turkey, and points out that literary texts used so far have offered no relevance to the student's immediate concerns, presented mostly too abstract tasks for nonnative speakers, made it possible only rephrasing and memorization and not enabled the students to give creative responses. He also draws attention to some linguists such as Topping (1968) who believed that literature does not contribute to the student's practical language needs, which reminds us of communicative approaches to literature in EFL classroom in the 1970s and 1980s.

As a result, today we usually assign a remarkable role for literature within the enterprise of language learning but still have difficulty in answering some questions clearly: Does literature really / and to what extent make a significant contribution to grammar and other language skills, to academic or occupational goals and to promoting individual and cultural awareness? Also of question in this paper is whether it is wise to leave behind the approaches prioritizing the referential language of authentic texts, instead of integrating the representational language offered by literary texts to the EFL curricula.

\section{Method}

\section{Turkish Context}

Although there might be some exceptions in some schools or institutions particularly private ones, Turkish students mostly follow an English curriculum in which literature of the target language is not regarded as an integral part of language teaching and learning. In other words, with some exceptions, activities conducted in language classroom do not include works from the target language such as poems, novels or short stories. In addition to this, as the language exams conducted in Turkey do not test productive skills such as speaking and writing together with listening, one of the receptive skills, most language teaching and learning focus mainly on grammar, vocabulary and reading. On account of the shortcomings presented by university placement exam, the students in ELT and language literature departments should be conceived as both English learners and prospective teachers. This further complicates the issue and suggests another problem in literature classes regarding the development of spoken and critical skills of Turkish participants. Moreover, students take literature courses with a limited scope and time.

\section{Participants}

The participants of this study were thirty Turkish EFL senior students at the department of foreign language education, Middle East Technical University. They were aged between 21-23, with an average of 21.5. Of the 30 participants, 23 were female and 7 were male. They were graduates of high schools where English is a compulsory subject. Age and sex into were not taken consideration. The participants were chosen 
using purposive sampling. It did not include the random assignment as the limited availability of the participants.

\section{Instruments}

To collect data, the survey developed by the researchers was used. It included 8 statements (Table 1) and the participants were asked to read each of the statements and indicate their agreement or disagreement on a 4-point Likert scale ( $1=$ I totally disagree, $2=$ I do not agree, 3= I agree, 4= I totally agree). In order to analyze data, descriptive statistics were applied. In this study, in addition to the

Table 1. quantitative measures, a semi-structured interview was used to find out which of the literature courses are found to be the most beneficial and the participants' evaluation of the methodology followed in the literature courses.

\section{Analysis and discussion}

As can be seen in Table 1, the participants totally agree that literature courses are necessary for their occupation as an English language teacher $(\mathrm{M}=3,63)$ and further acknowledge that they, as prospective English teachers, can benefit from literature courses in their future career $(M=2,97)$.

Descriptive statistics on the data gathered from the survey

\begin{tabular}{|c|c|c|c|}
\hline Statements & $\mathrm{N}$ & M & $\begin{array}{l}\text { Sd Agreement/ } \\
\text { Disagreement }\end{array}$ \\
\hline $\begin{array}{l}\text { 1.Literature courses are necessary for my occupation as an English language } \\
\text { teacher. }\end{array}$ & 30 & 3,63 & ,613 Totally agree \\
\hline 2.I benefit from literature courses in my practice teaching. & 30 & 2,23 & ,728 Disagree \\
\hline $\begin{array}{l}\text { 3.As a prospective English teacher, I think I can benefit from literature courses in } \\
\text { my future career. }\end{array}$ & 30 & 2,97 & ,809 Agree \\
\hline 4.My reading skill has improved in the literature courses. & 30 & 2,80 & ,887 Agree \\
\hline 5.My speaking skill has improved in the literature courses. & 29 & 2,03 & ,626 Disagree \\
\hline 6.My writing skill and lexical knowledge have improved in the literature courses. & 30 & 2,93 & ,691 Agree \\
\hline 7.My listening skill has improved in the literature courses. & 30 & 1,90 & ,548 Disagree \\
\hline 8.Specific courses on the use of lite & 30 & 3,23 & 1,073Agree \\
\hline
\end{tabular}

However, they disagree with the statement that they benefit from literature courses in their practice teaching $(\mathrm{M}=2,23)$. In other words, although the participants value literature courses, they cannot benefit from what they have learned and experienced. This result is caused by the fact that the literature courses are not an integral part of language teaching and learning in most of the schools in Turkey. Moreover, as the participants are evaluated and assigned a grade taking their teaching and the students' reaction into consideration and this evaluation is done during one class hour, the topics or subjects that can be covered in an hour are dealt with in practice teaching, ignoring activities related to literature taking more time, students' active participation and preparation.

Regarding the skills that they have used in the literature courses they have taken, the participants claimed that their reading $(M=2,80)$ and writing skills $(M=2,93)$ improved, whereas listening $(M=1$,
90) and speaking (2, 03) skills did not. This result revealed that the methodology followed in the literature courses consist of activities fostering reading and writing. However, although the nature of these courses provide a platform for discussion, speaking and listening, the current participants did not benefit from activities as, according to the participants, the instructor presented and analyzed most of the readings assigned. This finding is in alignment of with Türker's statement that literary texts should provide the students with an opportunity to give creative responses.

The participants agree that specific courses on the use of literary texts in ELT classes should be offered ( $M=$ $3,23)$. As Türker stressed that the use of literary texts be relevant to the students' immediate concerns such as how to use literary text in ELT, the participants recommended that the literature courses should also provide an answer to the question of how these texts can be used in ELT classes, going beyond the mere analysis. 
The semi-structured interview used to find out which of the literature courses are found to be the most beneficial. The participants' evaluation of the methodology revealed that the most beneficial were Drama and Novel courses as, as stated by the participants, the plays and novels analyzed in these courses provided the participants with the culture, values and morals in the target language. Introduction or survey courses were not found to be beneficial as these courses aimed to only provide a historical account.

The participants also stated that the activities followed in the literature courses included students' presentation and essay-writing on the assigned novels and play, leaving little space for discussion and critical thinking. They complained that although the aim is to foster critical thinking and empowering the students with the culture of the target language, the essays required them to provide factual facts from the assigned readings, which did not pave the way for discussion in contrast to what Ferradas, Premawardhena, Hall, Hussein and Widdowson argue regarding how literature can serve to improve critical abilities, strategies and cultural awareness.

Moreover, the participants recommended that literature courses not be restricted to mere literary analysis of certain texts and contemporary plays, stories or novels be also incorporated in the curriculum, which is in alignment with Tseng' remarkable note that stresses students have more pleasure in reading contemporary literature rather than classic literature.

\section{Conclusion}

An examination of research on pure literature classes reveals that the literature classes in the ELT department cannot corporate the literary appreciation with educational objectives regarding the students as both present learners of literature and prospective teachers of English. The participants recommended that the literature courses should not be limited to the canonic texts. As the mere analysis or factual details will just further prioritize the memorization over the critical thinking, appreciation and discussion, the contemporary readings that may corporate the literary appreciation with educational objectives will be highly beneficial to develop linguistic and communicative abilities through critical literary readings and cultural interpretative efforts.

\section{References}

Carter, R. (2007). Literature and language teaching 19862006: A review. International Journal of Applied Linguistics, 17(1), 3-13.

Ferradas, C. (2009). Enjoying literature with teens and young adults in the English language classroom. In F. O'Connell (Ed.), Britlit: Using literature in EFL classrooms (pp. 27-34). London: British Council.

Garvie, E. (1990). Story as vehicle. Clevedon: Multilingual Matters Ltd.

Hall, G. (2005). Literature in language education. London: Macmillan.

Hussein, N. (2007). Literature in language classroom: An inside view. Journal of State University of Bangladesh, 1(1), 113-120. Retrieved from http://www.sub.edu.bd/downloads/journal/ June07/8.\%20Hussain_2007.pdf

Montgomery, M., Durant, A., Fabb, N., Furniss, T. \& Mills, S. (2007). Ways of reading, advanced reading skills for students of English literature (3rd ed.). London: Routhledge.

McRae, J. (1991). Literature with a small ' $l$ '. London: Macmillan.

Widdowson, H. (1983). Talking shop: H. G. Widdowson on literature and ELT. ELT Journal, 37(1), 30-35.

Wright, A. (2003). The place of stories in ELT. In A. Paran \& E. Watts (Eds.), Storytelling in ELT. Whitstable, Kent: IATEFL.

Sivasubramaniam, S. (2006). Promoting the prevalence of literature in the practice of foreignand second language education: Issues and insights. The Asian EFL Journal Quarterly , 8(4), 254-273. Retrieved from http://www.asian-eflournal.com/December 2006_EBook.pdf

Unsworth, L. (2006). E-literature for children: Enhancing digital literacy learning. London: Routledge.

Premawardhena, N. C. (2009). Integrating literature into foreign language teaching: A Sri Lankan perspective. Novitas-ROYAL, 1(2), 92-97. Retrieved from http://www.novitasroyal.org/Neelakshe.pdf

Topping, D. M. (1968). Linguistics or literature: An approach to language. TESOL Quarterly, 2(2), 95100.

Tseng, F. (2010). Introducing literature to an EFL classroom: Teacher's presentations and students' perceptions. Journal of Language Teaching and Research, 1(1), 53-65. Retrieved from http://ojs.academypublisher.com/index.php/jltr/articl e/view/01015365/1508

Türker, F. (1991). Using Literature in Language Teaching. Hacettepe Üniversitesi Eğitim Fakültesi Dergisi, 6, 299-305. Retrieved from http://193.140.216.63/19916FARUK\%20T\%C3\%9C RKER.pdf 